\title{
The Relationship between Electricity Consumption, Oil Prices, and Economic Growth in Indonesia
}

${ }^{1 *}$ Prastowo, ${ }^{2}$ Laillil Putri Damayanti

Email : ${ }^{1 *}$ prastowo@ uii.ac.id , ${ }^{2}$ 14313458@ @students.uii.ac.id , Afiliation: ${ }^{12}$ Universitas Islam Indonesia, Indonesia

* Corresponding Author

\begin{abstract}
This study aims to analyze the relationship between electricity consumption, oil prices and economic growth. The data used are from 1971 to 2014 using a case study of the country of Indonesia. This research model uses the Vector Error Correction Model (VECM) regression. The results show that there is a long-term balance in electricity consumption, oil prices and economic growth. However, there is no short-term relationship on electricity consumption, oil prices and economic growth. Therefore, it is recommended that the government maximize the investment sector in industrialization so that the level of electricity consumption in terms of industry increases and can increase economic growth. In addition, this policy can create job opportunities so that residents can have greater job opportunities.
\end{abstract}

Article history

Received 2021-10-03

Revised 2021-10-27

Accepted 2021-11-02

\section{Keywords}

electricity consumption economic growth co-integration JEL Classification*: Q43, 040, C10

This is an open access article under the CC-BY-SA license.

\section{Introduction}

Economic dependence on electricity occurs in almost all countries, both developed and developing. The research of Narayan et al. (2008) in G7 member countries except the United States showed that the contribution of electrical energy had a significant impact on economic 
growth. Squali (2007) mentions in his research that some of the OPEC members' economic growth depends on electricity consumption, such as Indonesia, Nigeria, Iran, Qatar, and Venezuela.

Electricity consumption is an important component of economic growth. Directly and indirectly, electricity consumption is a complement to labor and capital as a factor of production (Costantini and Martini, 2010). This is the government's concern to develop electrical energy. The need for electricity will increase along with the social growth of society from time to time. Energy significantly and directly influenced the industrial revolution (Stern, 1997).

GDP and energy demand have a mutually influencing relationship so that GDP is one of the drivers of energy demand. Economic activity creates energy demand from energy consumption. Jumbe (2004) states that there is a causal relationship between energy and gross domestic product (GDP), which means that the economy depends on energy because energy is a stimulus for economic growth.

Toman and Jenelkova (2003) stated that most of the literature on energy and economic development discusses how development affects energy use, and not vice versa. So far, economists view economic growth as the main driver of energy demand. The unidirectional causal relationship from electricity consumption to economic growth shows that restrictions on electricity use can negatively affect economic growth, and conversely, increased electricity use can contribute to economic growth (Altinay and Karagol, 2005; Shiu and Lam, 2004).

Yoo and Kim's research (2006) which explains that the direction of the causal relationship between electricity consumption and economic growth in Indonesia is from economic growth to electricity consumption. Yoo's research (2006) explains that electricity consumption has no significant effect on economic growth in Indonesia. There is no direct causal relationship from electricity consumption to economic growth. According to Yoo (2006) caused by the small proportion of electricity use for economic activities that are directly related to the formation of GDP. On the other hand, research by Harsono and Kuncoro (2013) shows that there is no causal relationship, either from electricity consumption to economic growth or vice versa. Suryanto (2013) uses the variable of electricity consumption and economic growth, this study finds that there is no causal relationship between the selected variables

Furthermore, there is a link between oil prices. electricity consumption and economic growth. The research of Shahbaz et al. (2017) show that there is cointegration and feedback between electricity consumption and economic growth, oil prices and economic growth. This finding confirms that despite oil prices, developing countries are highly dependent on electricity consumption for economic growth. In the short term, economic growth and feedback suggest that stronger energy policies must be implemented to achieve sustainable economic growth in the long term. 
The issue of electricity consumption is an inseparable part in analyzing economic growth in developing countries, including Indonesia. This study aims to analyze the causal relationship between electricity consumption, oil prices and economic growth. Increased consumption of electrical energy will indirectly increase economic growth through the resulting output. However, the opposite can happen, economic growth will have an impact on increasing consumption of electrical energy because electrical energy is one of the important inputs in the production process. On the other hand, world oil prices fluctuate and may have an impact on economic growth and electricity consumption. This research is expected to make a new contribution to the previous literature.

\section{Literature Review}

The research of Narayan et al. (2008) tested the GDP shock reaction on electricity consumption using Structural Vector Autoregressive (SVAR) in G7 countries. The finding is that unless the United States shows the contribution of electrical energy has a significant impact on economic growth. Meanwhile, Squali (2007) examines the relationship between electricity consumption and economic growth in OPEC member countries using the Unrestricted Error Correction Model. Squali's findings show that some of the OPEC members' economic growth depends on electricity consumption, such as Indonesia, Nigeria, Iran, Qatar, and Venezuela. Consumption of electrical energy has an impact on economic growth, such as research conducted by Narayan et al. (2008) and Squali (2007)

Research in several countries shows that the consumption of electrical energy has an impact on economic growth. In contrast, the research of Ameyaw et al. (2017) in Ghana using VECM. Ameyaw's findings have an impact on electricity consumption. Economic growth encourages an increase in electricity consumption. Thus, only the research of Yoo and Kim (2006) using the Granger causality test, the direction of the causal relationship between electricity consumption and economic growth in Indonesia is from economic growth to electricity consumption.

Furthermore, the research of Tang et al. (2016) In particular, energy consumption, FDI and capital were found to be positive in influencing economic growth in Vietnam, a unidirectional causality running from energy consumption to economic growth. The findings of Bayramoglu and Yildirim (2016) show that the effect of energy consumption is asymmetric in the long term but not in the short term. In the long term, the effect of the negative component of energy consumption on economic growth is small and statistically insignificant.

Yoo's research (2006) explains the causal relationship between electricity consumption and economic growth in ASEAN member countries. The findings show that Indonesia and 
Thailand show economic growth to electricity consumption. On the other hand, Singapore and Malaysia have a two-way relationship between economic growth and electricity consumption. In addition, Narayan and Smyth (2009) examined Middle Eastern countries that the causal relationship between economic growth and electricity consumption is two-way.

Table 1. literature study

\begin{tabular}{|c|c|c|c|c|c|}
\hline no & autor(s) & Country & period & methodology & Finding \\
\hline & Ameyaw et al. & & & co-integratior & ; GDP -> EC; K.L -> \\
\hline \multirow[t]{2}{*}{1} & $(2017)$ & Ghana & $1970-2014$ & Granger causality - VECM & GDP \\
\hline & Narayan et al. & & & & EC positif signifikan \\
\hline 2 & $(2008)$ & G7 & 1993-2002 & SVAR & thp GDP, kecuali USA \\
\hline \multirow[t]{2}{*}{3} & Yoo dan kim (2006) & indonesia & $1971-2002$ & Granger causality & GDP $->$ EC \\
\hline & Harsono dan & & & co-integratior & \\
\hline \multirow[t]{6}{*}{4} & kuncoro (2013) & indonesia & $1984-2010$ & Granger causality - ECM & $\mathrm{ELC} \neq \mathrm{GDP}$ \\
\hline & & & & & GDP $->$ EC \\
\hline & & & & & (indonesia, \\
\hline & & & & & thailand); EC $<-$ \\
\hline & & & & & $>\mathrm{GDP}$ \\
\hline & & & & & (malaysia, \\
\hline \multirow[t]{2}{*}{5} & Yoo (2006) & ASEAN & $1971-2002$ & Granger causality & singapore) \\
\hline & Narayan dan Smyth & & & & \\
\hline \multirow[t]{2}{*}{6} & (2009) & MENA & $1974-2002$ & panel co-integration & $\mathrm{EC}<->\mathrm{GDP}$ \\
\hline & Bah dan azam & & & & \\
\hline \multirow[t]{2}{*}{7} & $(2017)$ & South Africa & $1971-2012$ & ARDL & GDP per capita $\neq$ EC \\
\hline & Shahbaz et al. & & & Panel cointegration; Grange & \\
\hline 8 & (2017) & OECD & $1960-2014$ & causality & $\mathrm{EC}<->\mathrm{GDP}$ \\
\hline
\end{tabular}

There is no causal relationship between economic growth and electricity consumption and vice versa in Indonesia. Research by Harsono and Kuncoro (2013) uses the Error Corrections Model (ECM). The findings show that there is no causal relationship, either from electricity consumption to economic growth or vice versa. Similar to Bah and Azam's research (2017) in South Africa, the results show that there is no causal relationship and no causal relationship between electricity consumption and economic growth and vice versa. Suryanto (2013) uses the variable of electricity consumption and economic growth, this study finds that there is no causal relationship between the selected variables. 
The research of Shahbaz et al. (2017) using cointegration panels in OECD member countries. His findings show the existence of cointegration and feedback between electricity consumption and economic growth, oil prices and economic growth. In addition, confirmed that despite the price of oil, developing countries are highly dependent on electricity consumption for economic growth.

\section{Research Methods}

This study uses time series data from 1971 to 2014. The data used in this study came from the publications of the World Bank and British Petroleum. In this study GDP as a variable of economic growth. Sources of data obtained from the publications of the world bank and British Petroleum.

Table 2. Data Description

\begin{tabular}{llll}
\hline Variable & Symbol & Source & Data measurement \\
\hline Economic Growth & GDP & World Bank & Constan 2000 US\$ \\
Electricity Consumption & EC & World Bank & Kwh Per capita \\
Total Population & POP & World Bank & People \\
Oil Price & OP & British Petroleum & US \$ per barel \\
\hline
\end{tabular}

The model developed in this study is using the Vector Error Correction Model (VECM) with the following equation form:

$$
\operatorname{LnGDP}_{t}=\alpha+\beta_{0} \operatorname{LnEC_{t}}+\beta_{1} \operatorname{LnOP}_{t}+\beta_{2} \operatorname{LnPOP_{t}}+\varepsilon_{t}
$$

To avoid sporius between variables, the researcher conducted two different unit root tests, namely Phillips-Perron (PP) and Augmented Dickey-Fuller (ADF) on time series data. Stationarity test of data can be done by unit root test and/or degree of integration test. If it is found that the data used has the same degree of integration I (1), then proceed with the cointegration test. Cointegration test to determine the long-term relationship of the model being observed. The PP root test is made by explaining where there is an autocorrelation between the disturbance variables without including an explanatory variable for differential lags (Widarjono, 2013). The next step is determining the optimum lag and testing the stability of VAR. The optimum lag value is the smallest value, then check the VAR stability condition in the form of roots of characteristic polynomial. A VAR is considered stable if all its roots have a modulus value less than one

It is important to test the co-integration between variables using Johansen's co-integration analysis. Johansen's (1988) procedure suggests using the maximum likelihood approach. Furthermore, this method starts from the process of testing the hypothesis equation $r=0$, where there is no cointegration vector. If the hypothesis cannot be rejected, then the procedure is 
stopped because the variables are not cointegrated. If the hypothesis $r=0$ is rejected, it is possible to perform a test on almost (at most) 1 cointegration vector ( $\mathrm{r}$ 1). Finally, the causality test is used to find a causal relationship or causality test between endogenous variables in the VAR system. This causality test can use the Granger causality method (Widarjono, 2007).

\section{Result and discussion}

The stationarity test in this study used the Augmented Dickey-fulley and Phillips-Perron methods. Based on the results of the Augmented Dickey-Fulley and Phillips-Perron root tests, Tables 3 and 4 can be concluded that all variables, both electricity consumption, economic growth, oil prices and population, have a unit root test which means they are stationary in the first difference..

Table 3. Result of Root Test Augmented Dickey-Fulley

\begin{tabular}{|c|c|c|c|c|c|c|c|c|}
\hline \multirow{2}{*}{ variabel } & \multicolumn{3}{|c|}{ Level } & \multirow{2}{*}{ Ket } & \multicolumn{3}{|c|}{$1^{\text {st }}$ different } & \multirow{2}{*}{ Ket. } \\
\hline & 1 & 2 & 3 & & 1 & 2 & 3 & \\
\hline LEC & 0.1165 & 0.9853 & 0.9977 & TS & $0.0003^{*}$ & $0.0003^{*}$ & 0.1796 & $S$ \\
\hline LGDP & 0.4637 & 0.4059 & 1.0000 & TS & $0.0005^{*}$ & $0.0023^{*}$ & $0.0253^{*}$ & $S$ \\
\hline LOP & 0.1953 & 0.4941 & 0.8619 & TS & $0.0000^{*}$ & $0.0000^{*}$ & $0.0000^{*}$ & $S$ \\
\hline LPOP & $0.0031^{*}$ & 0.3953 & 0.8695 & $S$ & 0.5277 & $0.0122^{*}$ & 0.0687 & $S$ \\
\hline
\end{tabular}

Table 4. Result of Root Test Phillips-perron

\begin{tabular}{|c|c|c|c|c|c|c|c|c|}
\hline \multirow{2}{*}{ Variabel } & \multicolumn{3}{|c|}{ Level } & \multirow{2}{*}{ ket } & \multicolumn{3}{|c|}{$1^{\text {st }}$ different } & \multirow{2}{*}{ ket } \\
\hline & 1 & 2 & 3 & & 1 & 2 & 3 & \\
\hline LEC & 0.1545 & 0.9804 & 1.0000 & TS & $0.0004^{*}$ & $0.0004^{*}$ & $0.0164^{*}$ & $\mathrm{~S}$ \\
\hline LGDP & 0.5336 & 0.5451 & 1.0000 & TS & $0.0005^{*}$ & $0.0000^{*}$ & $0.0353^{*}$ & S \\
\hline LOP & 0.1913 & 0.4828 & 0.8619 & TS & $0.0000^{*}$ & $0.0000^{*}$ & $0.0000^{*}$ & $S$ \\
\hline LPOP & $0.0000 *$ & $0.0360^{*}$ & 1.0000 & $\mathrm{~S}$ & 0.3795 & 0.9789 & $0.0000 *$ & $\mathrm{~S}$ \\
\hline
\end{tabular}

Note, *stasioner dari alfa 5 persen, TS: Tidak Stasioner, S: Stasioner 1 (intercept), 2 (trend \& intercept), 3 (none)

source: secondary data processed

Determination of optimal lag is done by selecting the smallest number of akaike Information Criterion (AIC), Schwarz Criterion (SC), and Hannan-Quinn Criterion (HQ). The maximum lag length used in this study is the 3rd lag. Table 5 shows that the lag values are in lag 3 , where in this lag there are the lowest values for the akaike information criterion (AIC), final prediction error (FPE), and Schwarz information criterion (SC). Then the optimum lag length is at lag 3. 
Table 5. Result of Optimum Lag Length Test

\begin{tabular}{cccc}
\hline Lag & AIC & SC & HQ \\
\hline 0 & -3.492912 & -3.325734 & -3.432035 \\
1 & -19.43358 & -18.59769 & -19.12919 \\
2 & -21.25351 & -19.74891 & -20.70562 \\
3 & $-24.73485^{*}$ & $-22.56154^{*}$ & $-23.94345^{*}$
\end{tabular}

*) lag optimum

A VAR condition stability check was carried out in the form of roots of characteristic polynomial to test whether the VAR estimate was stable or not. If all the roots have a modulus less than one, then a VAR system can be said to be stable. Table 6 shows that the results of the VAR stability test can be concluded that the VAR system is stable because the tested modulus has a value of less than one, which is between $0.423175-0.978204$ so it can be concluded that the VAR model formed is stable at its optimal lag.

Table 6. Stability Model test result

\begin{tabular}{cc}
\hline Root & Modulus \\
\hline 0.978204 & 0.978204 \\
0.966273 & 0.966273 \\
$0.649183-0.131592 \mathrm{i}$ & 0.662386 \\
$0.649183+0.131592 \mathrm{i}$ & 0.662386 \\
$0.391257-0.411193 \mathrm{i}$ & 0.567592 \\
$0.391257+0.411193 \mathrm{i}$ & 0.567592 \\
$0.256423-0.336638 \mathrm{i}$ & 0.423175 \\
$0.256423+0.336638 \mathrm{i}$ & 0.423175 \\
\hline
\end{tabular}

source: secondary data processed

Cointegration test is carried out using the Johansen Cointegration method using lag 3. Based on Table 7, the results of the trace statistic value are greater than the critical value of 5 percent, namely $94.09026>47.85613$, as well as the Max Eigen Statistic value which is greater than the critical value of 5 percent, namely $50.02779>27.58434$ which means there is a cointegration in the equation model.

Table 7. Cointegration Test Results

\begin{tabular}{ll}
\hline Hypothesized & trace \\
\hline
\end{tabular}


JAMPE Vol. 1. No 1, January 2022 pp. 28-39

\begin{tabular}{ccccc}
\hline No. of CE(s) & $\begin{array}{c}\text { Trace } \\
\text { Statistic }\end{array}$ & $\begin{array}{c}0.05 \\
\text { Critical value }\end{array}$ & $\begin{array}{c}\text { Max- Eigen } \\
\text { Statistic }\end{array}$ & $\begin{array}{c}0.05 \\
\text { Critical value }\end{array}$ \\
\hline None $^{*}$ & 94.09026 & 47.85613 & 50.02779 & 27.58434 \\
\hline At most 1 & 44.06247 & 29.79707 & 33.87710 & 21.13162 \\
\hline At most 2 & 10.18537 & 15.49471 & 6.996815 & 14.26460 \\
\hline At most 3 & 3.188555 & 3.841466 & 3.188555 & 3.841466 \\
\hline
\end{tabular}

source: secondary data processed

Table 8. Granger Causality Test Results

\begin{tabular}{lcccc}
\hline Null Hypothesis: & Obs & F-Statistic & Prob. & Keterangan \\
\hline LGDP does not Granger Cause LEC & 42 & 0.99681 & 0.3788 & LGDP $\neq$ LEC \\
LEC does not Granger Cause LGDP & & 0.16106 & 0.8518 & LEC $\neq$ LGDP \\
\hline LOP does not Granger Cause LEC & 42 & 0.04210 & 0.9588 & LOP $\neq$ LEC \\
LEC does not Granger Cause LOP & & 0.10668 & 0.8991 & LEC $\neq$ LOP \\
\hline LPOP does not Granger Cause LEC & 42 & 3.83146 & 0.0307 & LPOP $\rightarrow$ LEC \\
LEC does not Granger Cause LPOP & & 1.03954 & 0.3637 & LEC $\neq$ LPOP \\
\hline LOP does not Granger Cause LGDP & 42 & 0.22233 & 0.8017 & LOP $\neq$ LGDP \\
LGDP does not Granger Cause LOP & & 0.03024 & 0.9702 & LGDP $\neq$ LOP \\
\hline LPOP does not Granger Cause LGDP & 42 & 3.26666 & 0.0494 & LPOP $\rightarrow$ LGDP \\
LGDP does not Granger Cause LPOP & & 0.36689 & 0.6954 & LGDP $\neq$ LPOP \\
\hline LPOP does not Granger Cause LOP & 42 & 2.95855 & 0.0643 & LPOP $\rightarrow$ LOP \\
LOP does not Granger Cause LPOP & & 4.28308 & 0.0212 & LOP $\rightarrow$ LPOP \\
\hline
\end{tabular}

source: secondary data processed

Table 8 shows the results of the Granger causality test between economic growth, electricity consumption, and oil prices that do not affect each other. Meanwhile, the relationship between the electricity consumption variable and the population is one-way where the population encourages electricity consumption and economic growth.

Based on the results shown in table 9, in the short term, electricity consumption has a significant positive effect on electricity consumption in the current period. Meanwhile, economic growth and oil prices have a significant negative effect on electricity consumption. Furthermore, based on the long-term estimation results, it is known that the variable economic growth at lag 1 has a significant positive effect on electricity consumption with a coefficient of 0.50 . If there is an increase in economic growth, it will cause an increase in electricity consumption in the long term by 0.5 percent. Meanwhile, oil prices and population have a significant negative effect on electricity consumption with coefficients of -0.38 and -2.28 , respectively. This means that if there is an increase in oil prices, it will cause a decrease in electricity consumption in the long term by 
0.38 percent, while an increase in the population causes a decrease in electricity consumption in the long term by 2.28 percent. So it can be concluded that in the long term (forty four years according to the research period 1971-2014) it is known that the variables of economic growth, oil prices and population have a significant effect on electricity consumption.

Table 9. VECM result

\begin{tabular}{|c|c|c|c|}
\hline \multicolumn{4}{|c|}{ Hubungan Jangka Panjang } \\
\hline variabel & koefisien & t-statistik & Keterangan \\
\hline D(LGDP $(-1))$ & 1.176625 & $4.62174^{* *}$ & Signifikan \\
\hline $\mathrm{D}(\mathrm{LOP}(-1))$ & -0.384678 & $-3.85166^{* *}$ & Signifikan \\
\hline $\mathrm{D}(\mathrm{LPOP}(-1))$ & -2.288780 & $-2.63073^{* *}$ & Signifikan \\
\hline \multicolumn{4}{|c|}{ Hubungan Jangka Pendek } \\
\hline Variabel & Koefisien & T-statistik & Keterangan \\
\hline CointEq1 & -0.405385 & $-3.78539 * *$ & Signifikan \\
\hline $\mathrm{D}(\operatorname{LEC}(-1))$ & 0.416161 & $2.04072^{* *}$ & Signifikan \\
\hline $\mathrm{D}(\mathrm{LEC}(-2))$ & -0.170974 & -1.45551 & Tidak signifikan \\
\hline $\mathrm{D}(\operatorname{LEC}(-3))$ & 0.359154 & $2.95121^{* *}$ & Signifikan \\
\hline $\mathrm{D}(\operatorname{LGDP}(-1))$ & 0.403415 & $1.72207^{*}$ & Signifikan \\
\hline $\mathrm{D}(\operatorname{LGDP}(-2))$ & 0.619142 & $2.62907^{* *}$ & Signifikan \\
\hline D(LGDP $(-3))$ & 0.008043 & 0.03568 & Tidak signifikan \\
\hline $\mathrm{D}(\mathrm{LOP}(-1))$ & -0.123285 & $-3.84294^{* *}$ & Signifikan \\
\hline $\mathrm{D}(\mathrm{LOP}(-2))$ & -0.196506 & $-6.69869 * *$ & Signifikan \\
\hline $\mathrm{D}(\mathrm{LOP}(-3))$ & -0.078901 & $-2.26099 * *$ & Signifikan \\
\hline D(LPOP(-1)) & -101.0056 & -0.48464 & Tidak signifikan \\
\hline D(LPOP(-2)) & 8.192675 & 0.02379 & Tidak signifikan \\
\hline D(LPOP(-3)) & -29.26346 & -0.17619 & Tidak signifikan \\
\hline $\mathrm{C}$ & 2.176287 & $3.60206^{* *}$ & Signifikan \\
\hline
\end{tabular}

Note: signifikasi ${ }^{* *}$ ) $\left.\left.1 \%,{ }^{* *}\right) 5 \%,{ }^{*}\right) 10 \%$

source: secondary data processed

Based on the results of the unit root test, all variables are stationary at the first different level, both in the Augmented Dickey-Fulley and Phillips-Perron tests so that the LGDP, LEC, LOP, LPOP variables have long-term equilibrium. Furthermore, the results of the cointegration test between LGDP, LEC, LOP, and LPOP have a long-term equilibrium relationship, this is in accordance with the hypothesis in this study.

The results of the study show that there is a long-term balance relationship between electricity consumption and economic growth in Indonesia. In line with the research of Shahbaz et al. (2017), his findings show a long-term balance relationship between electricity consumption 
and economic growth, oil prices and economic growth. This finding confirms that developing countries are highly dependent on electricity consumption for economic growth despite high oil prices.

The results of the causality test found that there was no reciprocal or direct relationship between electricity consumption and economic growth, the results of this study were in line with research (Suryanto, 2013) and Yoo (2006) which also stated that there was no relationship between economic growth and electricity consumption in Indonesia. . This means that high electricity consumption does not always indicate that economic growth is also high, this is due to the small proportion of electricity consumption for economic activities.

Likewise, the results of research by Bah and Azam (2016) stated that there was no relationship between electricity consumption and economic growth. Research by Harsono and Kuncoro (2013) uses the Error Corrections Model (ECM). The findings show that there is no causal relationship and balance in the long term, both from electricity consumption to economic growth and vice versa.

Causality relationship between electricity consumption and population that there is a unidirectional relationship. Currently, there are many modern technologies that can facilitate one's mobility. Likewise, the modernization of medical equipment that uses a lot of electricity can help in medical matters so as to maximize treatment results and increase the standard of living. In line with the hospital industry and medical personnel who use a lot of electricity. There is no reciprocal or unidirectional relationship between economic growth and oil prices. The level of imports of Indonesian fuel oil is still relatively low because fuel consumption is part of domestic production. Meanwhile, Jayaraman and Lau (2011) stated that in the short term oil prices have an impact on economic growth in Pacific Island countries. The country is dependent on oil imports so that changes in oil prices have an impact on economic growth. Likewise, there is no reciprocal or direct relationship between electricity consumption and oil prices. Most of Indonesia's electricityproducing raw materials come from coal.

\section{Conclusion}

This study aims to analyze the relationship between electricity consumption, oil prices and economic growth in Indonesia for the period 1971-2014. Based on the results of the study, it can be concluded that there is no causal relationship between electricity consumption, oil prices and economic growth. Meanwhile, there is a long-term balance relationship between electricity consumption, oil prices, and economic growth. The author's suggestion based on the conclusions above is that the government should maximize the investment sector in industrialization so that the level of electricity consumption in terms of industry increases and can increase economic 
growth. In addition, this policy can create job opportunities so that residents can have greater job opportunities.

\section{References}

Ameyaw, B., Oppong, A., Abruquah, L.A. and Ashalley, E. (2017). Causality Nexus of Electricity Consumption and economic Growth: An Empirical Evidence from Ghana. Open Journal of Business and Management , Vol.5, 1-10.

Altinay, G. dan Karagol, E.(2005), Electricity consumption and economic growth: evidence from Turkey. Energy Economics, Vol. 27, . 849-856.

Bah, MM. \& M. Azam (2017). Investigating the relationship between electricity consumption and economic growth: Evidence from South Africa. Renewable and Sustainable Energy Reviews Vol.80, 531-537

Bayramoglu, Arzu Tay. dan Ertugrul Yildirim. (2017). The Relationship between Energy Consumption and Economic Growth in the USA: A Non-Linear ARDL Bounds Test Approach. Energy and Power Engineering, 9, 170-186.

Costantini, V. and Martini, C. (2010). The Causality between Energy Consumption and Economic Growth: A Multi-Sectoral Analysis Using Non-Stationary Cointegrated Panel Data. Energy Economics, 32: 591-603.

Harsono, T.D. \& M. Kuncoro. (2013). Electricity Consumption and Economic Growth: A Casuality Evidence from Indonesia, 1984-2010. International Journal of Business, Economics and Law, Vol. 2, Issue 2

Jayaraman, Tiru K. dan evan Lau. (2011). Oil Price and Economic Growth in Small Pacific Island Countries. Modern Economy, 2, 153-162

Johansen, S. (1988). Statistical Analysis of Cointegration Vectors , Journal of Economic Dynamics and Control, Vol. 12, 231-54.

Jumbe, C. B. L. (2004). Cointegration and Causality between Electricity Consumption and GDP: Empirical Evidence from Malawi, Energy Economics (26), 61-68.

Narayan, P.K., Smyth, R., (2008). Energy consumption and real GDP in G7 countries: new evidence from panel cointegration with structural breaks. Energy Economics Vol.30, 2331-2341.

Narayan, PK \& Smyth R. (2009) Multivariate Granger-causality between electricity consumption, exports, and GDP: evidence from a panel of middle eastern countries. Energy Policy, Vol.37, 229-236.

Shahbaza, M., Sarwar, S., Wei Chen, Malik, M.N., (2017). Dynamics of electricity consumption, oil price and economic growth: Global perspective. Energy Policy Vol.108,256-270 
Shiu, A. dan Lam, P.L(2004), Electricity Consumption and Economic Growth in China. Energy Policy, 32(1), 47-54.

Stern, D.I. (1997) Limits to Substitution and Irreversibility in Production and Consumption: A Neoclassical Interpretation of Ecological Economics. Ecological Economics, 21, 197-215.

Suryanto, Yusuf (2013) Konsumsi Energi Listrik Dan Pertumbuhan Ekonomi di Indonesia : Aplikasi dan Model. MAJALAH.indd Spread 10 of 44 - Pages(10, 79) Edisi 03/Tahun XIX/201

Squali, J. (2007). Electricity consumption and economic growth: bounds and causality analyses of OPEC countries. Energy Economics Vol.29, 1192-1205.

Tang, Chor Foon. Tan, B.E, dan Ozturk, I. (2016). Energy consumption and economic growth in Vietnam. Renewable and Sustainable Energy Reviews 54, 1506-1514

Toman, M. A., Jemelkova, B. (2003) "Energy and Economic Development: An Assessment of the State of Knowledge", The Energy Journal 24: 93-112.

Widarjono, A (2007), Ekonometrika Teori dan Aplikasi untuk Ekonomi dan Bisnis. Ekonisia, Yogyakarta.

Widarjono, A. (2013), Ekonometrika Teori dan Aplikasi. Yogyakarta: UPP STIM YKPN.

Yoo, SH. (2006). The causal relationship between electricity consumption and economic growth in the ASEAN countries. Energy Policy Vol. 34,3573-3582.

Yoo, SH. \& Kim Y. (2006). Electricity Generation and Economic growth in Indonesia. Energy Vol.31 ,2890-2899. 